\section{THE LIFE CYCLE OF HEDGE FUNDS}

O CICLO DE VIDA DOS FUNDOS MULTIMERCADO
Recebido em 30.01.2021 Aprovado em 24.06.2021

Avaliado pelo sistema double blind review DOI: https://doi.org/10.12712/rpca.v15i2.48537

\author{
Silvia Franco de Oliveira \\ silvia.oliveira@mackenzie.br \\ Universidade Presbiteriana Mackenzie - São Paulo/SP, Brasil \\ http://orcid.org/0000-0001-7303-4939
}

\title{
Caroline Abreu Fila
}

carolinea.fila@gmail.com

Universidade Presbiteriana Mackenzie - São Paulo/Estado, Brasil

\begin{abstract}
This paper studies the lifecycle of hedge funds in Brazil from 2010 to 2018. A quantitative research was carried out using descriptive and multivariate statistical techniques in SPSS v.24. As expected, lagged net fund flows, current alpha and lagged alpha positively affect current net fund flows, however, contrary to expectations, alpha amplitude positively influences current net fund flows, and no evidence was found that age influence current net fund flows. The results also indicate that lagged net fund flows, current alpha, lagged alpha and age have a negative influence on the probability of liquidation or merger of fund.
\end{abstract} Keywords: Hedge Funds. Flow. Age. Alpha. Volatility.

\section{Resumo}

Este artigo estuda o ciclo de vida dos fundos de hedge no Brasil de 2010 a 2018. Foi realizada uma pesquisa quantitativa utilizando técnicas estatísticas descritivas e multivariadas no SPSS v.24. Como esperado, os fluxos de fundos líquidos defasados, alpha atual e alpha defasado afetam positivamente os fluxos de fundos líquidos correntes, no entanto, ao contrário das expectativas, a amplitude do alfa influencia positivamente os fluxos de fundos líquidos correntes, e nenhuma evidência foi encontrada de que a idade influencia os fluxos de fundos líquidos correntes. Os resultados também indicam que os fluxos de fundos líquidos defasados, alpha atual, alpha defasado e idade têm uma influência negativa na probabilidade de liquidação ou fusão de fundos.

Palavras-chave: Fundos Multimercado. Fluxo. Idade. Alpha. Volatilidade. 


\section{Introduction}

At the end of the 1980s, demand for hedge funds increased sharply in the United States, due to its prominence for its greater capacity to generate returns. However, as the sizes of the hedge funds increased, they showed difficulties in maintaining their expressive returns.

According to Petersen (2007), the demand for hedge funds in Brazil has become more expressive since 2002, motivated by the non-rupture of the economic model, started in the 1990s. The economic model sought macroeconomic balance, which implied a reduction in the rate interest rate (Selic). The fall in interest rates encouraged investors to seek more profitable and, consequently, riskier alternatives.

Several studies have been carried out on hedge funds in order to verify whether they are capable of generating real alpha for their investors. Alpha generation measures the ability of managers to predict market fluctuations. Because the United States is the pioneer and the largest holder of the hedge funds industry, both in volume and in number of funds, most studies are from American authors, using a sample of funds domiciled in the United States.

However, despite the increase in interest on the subject, there is a limited understanding of what drives the life cycle of hedge funds. Due to this limited understanding, the present paper aims to answering the following research problem: What are the drivers of hedge fund lifecycles?

First, the paper analyzes how current fund flows is affected by lagged fund flows, current performance, lagged performance, performance amplitude, and age.

According to Getmansky (2012), lagged fund flows positively affects current fund flows, lagged performance positively affects current fund flows, performance standard deviation negatively affects current fund flows, and age negatively affects current fund flows.

The positive influence of performance on the fund flows is also confirmed by Aragon et al. (2014), Fung et al. (2008) and Ramadorai (2013). The negative influence of age on the fund flows is also confirmed by Gao et al. (2019).

Second, the paper analyses whether the fund flows is influenced by the category to which the fund belongs.

Getmansky (2012) states that funds with directional strategies, that is, strategies that follow trends, are more responsive to previous returns. Funds that are more oriented towards market conditions, company restructuring and peculiar events are less responsive to past returns.

Third, the paper analyzes whether fund flows, fund performance and age affect the liquidation probability or merged probability.

Getmansky (2012) states that past fund flow, past performance and current performance negatively affect the liquidation probability; age positively affects the liquidation probability. Berk and Green (2004), Vayanos (2004), Fung et al. (2008) and Gao et al. (2012) also state that lower fund flows due to poor performance can lead to fund liquidation.

According to Getmansky (2012), hedge funds compete for limited opportunities and capital, increasing the fund's probability of liquidation. In other words, as the investor looks for better returns by category, the fund's probability of liquidation increases due to competition. The author understands that hedge funds have very distinct categories with a high barrier to entry, as it takes a lot of time and talent to establish a fund in a specific category. Analyzing the positioning of the category, it is possible to understand the fund's life cycle. 
This paper has five sections. In addition to the introduction, the theoretical review is presented. Subsequently, the methodological choices of empirical research are presented. Next, the paper contemplates the analysis of empirical data. To end up, the final considerations are presented..

\section{Theoretical reference}

The name hedge fund was publicly used, for the first time, in the 1966 Fortune Magazine by Carol J. Loomis. The author referred to the strategy of Alfred W. Jones, an Australian investor and manager. The strategy consisted of minimizing risks, maintaining a long-term share position and selling shares in the short term. (PETERSEN, 2007).

The fund managed by Alfred W. Jones was highly successful in generating significantly higher returns than the Mutual Funds, despite charging a high rate of return, about $20 \%$ of the net return. Another differential was the fund's ability to present de-correlated returns, that is, to offer alpha generation resulting from the manager's allocation ability, regardless of market direction. (PETERSEN, 2007).

According to Petersen (2007, p.5), the hedge fund is defined as "an investment fund whose objective is to obtain the highest possible return using all the investment possibilities available to the manager". To this end, the fund should use various market instruments and techniques in order to reduce volatility and still achieve an attractive return that is unrelated to market developments.

These funds differ from Mutual Funds and other investment vehicles, both in their internal structure and in their investment discipline. hedge fund managers can buy or sell securities they do not own, and are not restricted to common strategies. (GETMANSKY, 2012).

Due to the fact that they are complex, these funds are more suitable for professional investors or investors with high equity. (PETERSEN, 2007). These characteristics influence the flow of funds, as investors will analyze the category to which the hedge fund belongs. Investors can choose funds specialized in directional strategies more related to past returns ("Global Macro" or "Dedicated Short Seller") or categories less related to past returns (market conditions, company restructuring or other peculiar events). (GETMANSKY, 2012).

According to Getmansky (2012), since the late 1980s, the number of hedge funds has increased, on average, more than $15 \%$ per year. While in 1990 there were 610 funds managing US\$ 39 billion, in 2009 the author estimates that US\$ 1.465 billion was managed by more than 9000 hedge funds.

Despite the success and significant increase in demand for hedge funds, Avramov et al. (2011) portray the difficulty of these funds during the 2008 crisis. Many managers, hitherto successful, were hit with significant losses. Investors who, until then, were conditioned to expect high returns from these funds, had negative surprises. So, they massively withdrew their positions.

According to Joenväärä et al. (2019), the crisis ended up selecting hedge funds and the persistence of performance was significantly reduced. According to the authors, the performance of the portfolios was significantly reduced after the introduction of diversification requirements, as well as additional restrictions related to the size of the investment, liquidity, transaction cost, legal reviews, among other operational considerations that could reduce the alpha. These restrictions on the level of investors have an effect on hedge fund investors' expectations of return.

The financial market in Brazil has been growing substantially in terms of the amount and volume of funds managed. According to Bragança and Pessoa (2017), the total net equity of Brazilian funds was R\$ 538.1 billion in 2003, rising to $\mathrm{R} \$ 2.4$ trillion in 2013. This represents an increase of $346 \%$ in ten years (average of $16 \%$ per annum). 
According to the Brazilian Association of Entities in the Financial and Capital Markets (ANBIMA, 2020a), in July 2020, the net worth of Brazilian funds reached $\mathrm{R} \$ 5.7$ trillion, an increase of $138 \%$ since 2013 (average of 13\% per annum). Despite a drop in the average annual rate, it still shows significant market growth.

Brazilian hedge funds achieved a significant increase in shareholders' equity, from $\mathrm{R} \$ 600$ billion in 2004 to $\mathrm{R} \$ 2.1$ trillion in 2012, an increase of $250 \%$ in the period (average of $13 \%$ pa ). (BRAGANÇA; PESSOA, 2017). However, multimarket funds did not keep up with the market growth in the period from 2012 to 2020, reaching R \$ 1.3 trillion in Jul / 20, that is, a decrease of -38\% in the period (average of $-5.8 \%$ per annum). (ANBIMA, 2020a). This means that multimarket funds started to receive a significant amount of withdrawals.

The massive withdrawals occurred because the growth of fund industry makes it difficult for managers to allocate correctly, as it becomes more complex. In other words, the possibility of investing in several markets makes it difficult to find a performance evaluation model that is capable of capturing all movements. (BRAGANÇA; PESSOA, 2017).

In Brazil, hedge funds are free to allocate their resources in interest, commodities, debt, foreign exchange and shares. (BRAGANÇA; PESSOA, 2017). With the sophistication of investment funds and the creation of new products, it became necessary to classify the funds so that the investor can make a more mature and conscious decision. The classification facilitates the comparison of the performance of funds, as it helps in the construction of funding and profitability indicators, contributing to increase the transparency of the market. Segregation also functions as a tool for monitoring funds, improving conditions for discipline and inspection by regulatory bodies. (ANBIMA, 2020b).

For the composition of a portfolio, according to the asset portfolio selection theory, the investor must take into account the offer price, the degree of risk, the trading conditions, the profitability and the liquidity premium. (COSTA, 1999). For the investor to choose his portfolio of assets, it is necessary to analyze the trinomial profitability - security - liquidity. (MACHADO, 2008).

The more predictable the withdrawals or the sale value, the greater the investor's security and, consequently, the lower the investment risk. (CAVALCANTE et al, 2005). The decision of the relationship between risk and return, therefore, is a decision determined by the risk aversion of the investor. (ASSAF NETO, 2006).

According to Machado (2008, p.25) "risk can be understood by the ability to measure the state of uncertainty of a decision by knowing the probabilities associated with the occurrence of certain results or values".

As approached by Eboli (2006, p. 7) "Hedge fund managers take speculative positions with a high level of risk using a variety of financial instruments". Considering the speculative characteristics of hedge funds, it is possible to understand that the investment may incur risks of loss of capital, partial or total.

It is intuitive, therefore, to associate that in order to increase the alpha generation capacity of funds, it is necessary to incur greater risks.

The collection of higher administrative fees helps to align interests between investors and fund managers, since the higher the return achieved, the higher the remuneration for those who manage. That is why, in addition to the management fee charged on the fund's equity, there is also a performance fee, ranging from $15 \%$ to $25 \%$ of the return on the fund's benchmark. (GOETZMANN et al, 2001).

However, the excessive incentive to take risk can lead to a problem known as the principal and agent. The heart of the problem is the possibility that the principal (investor) and agent (manager) have contradictory interests regarding the risk to be taken. (PETERSEN, 2007). 
To reduce this asymmetry, hedge fund managers have significant personal investment in the fund, an attitude commonly known as "skin in the game" (risking their own skin), with the aim of further increasing the alignment of interests between the two parties. Clauses in the fund's regulation, such as the commitment of the manager's assets in the event of bankruptcy, supervision by the authorities and transparency in the disclosure of resources are also important measures to reduce the conflict. (PETERSEN, 2007).

The dimension of the hedge fund industry is such that the classification of strategies and their parameterization turns out not to be a trivial task. This also applies to the question of risk. In addition to credit, market, operational and legal risks, hedge funds also present liquidity, human, change in strategy and size risks. (PETERSEN, 2007). The description of each of them is available below:

- Credit risk occurs when the principal, earnings and interest, pledged by the securities held by the fund in its asset portfolio, are not received. (ASSAF NETO, 2006). (ASSAF NETO, 2006).

- Market risk occurs as a result of fluctuations in economic and financial variables, such as interest rates, exchange rates, etc. This risk is assuming a relevant position in the financial system due to several factors: global financial crises, new product development, deficient risk management, higher capital requirements, etc. (GOULART, 2003).

- Operational risk is the risk arising from failure of the information system, fraud, failure of computers, etc. There are basically three origins: process, human and technology. (ASSAF NETO, 2006).

- Legal risk occurs when there is no updated and efficient legislation. (ASSAF NETO, 2006).

- Liquidity risk occurs when the manager is unable to leave his position quickly or when a margin call is required due to leveraged positions. (PETERSEN, 2007).

- Human risk is related to the quality of managers, and the integrity of the management team is fundamental. (PETERSEN, 2007).

- The risk of a change in strategy occurs when the manager changes his strategy without communicating to investors. An example of forced change is when the fund's equity grows very fast, requiring the manager to search for new markets. (PETERSEN, 2007).

- The risk of asset size must be considered. The higher the equity, the more difficult it is to change positions and execute orders quickly. In addition, it increases the time spent on administrative, organizational and managerial tasks. (PETERSEN, 2007).

As can be seen, the definitions of risk are gaining greater precision and institutions assume a certain amount of risk as being normal in their operations. (MACHADO, 2008). But, can assuming an excess of risk be one of the reasons for the liquidation of a hedge fund?

The hedge funds industry saw a prolonged boom that lasted from 1920, the decade of its creation, until 2007, when the international financial crisis occurred. However, alongside this growth, another important event also occurred, a very high annual hedge funds liquidation rate $(7.10 \%)$ when compared to the mutual funds liquidation rate $(1.00 \%)$. In 2008, at the height of the international financial crisis, the liquidation rate reached $23 \%$, the average return was $-18 \%$ and $70 \%$ of hedge funds showed a negative performance. (GETMANSKY, 2012).

The liquidation of a fund can manifest itself in two ways: failure or closure, and the factors that can lead to each them are diverse. Failure can result from poor performance, fraud, the existence of a margin call, a concentrated bet that goes against the manager's strategy, among others. The closure may result from opportunities that ran out within a category, not being able to have more capital, poor performance of fund, among others. (GETMANSKY, 2012). 
As approached by Getmansky (2012), and also proposed by Berk and Green (2004), as investors evaluate the investment options available and make their decisions based on the attractiveness of returns, their flow increases and their probability of liquidation decreases. In other words, higher returns lead to higher future flows of resources.

On the other hand, unattractive returns generate negative fundraising, increasing the probability of liquidation. Fund managers are responsible for managing equity on behalf of the investors. However, when performing this task, they face the probability that these individuals can withdraw their assets at any time, that is, that the flows are negative, and it is natural to mark out withdrawals to be made based on performance. This creates a natural link between volatility and preference for liquidity. (GETMANSKY, 2012).

It may also occur that the smaller fund tends to increase its risk in order to obtain higher returns. Generally, the smallest funds are the youngest. (GETMANSKY, 2012). Following this line of reasoning, Barras et al (2010) advises that investors look for smaller and newer funds, since they are the ones that have the highest number of qualified funds. A similar idea is put forward by Gao et al (2019), who suggest that, in order to create a portfolio that maintains good performance, it is necessary to select small funds with a strong performance incentive.

Funds that have experienced high flows in the past, that is, have increased considerably in size as a result of new investments, have poorer returns in the following year. (AGARWAL et al, 2009). Therefore, having good returns in the past does not guarantee good returns in the future. Gao et al (2019) claim that a fund's performance decreases with age, suggesting that chasing past performance may be poorly recommended for investors.

According to Getmansky (2012), as the fund becomes more mature and larger, it tends to employ less risky strategies, that is, less volatile, generating lower returns. But, Gentilini (2014) states that this moment can be avoided, as managers can invest their capital in new ideas. Getmansky (2012) believes that diversification of investments can be beneficial to the fund by enabling volatility to be reduced. This means that the decrease in volatility can occur through diversification. The increase in the size of fund implies greater flexibility with regard to investment in uncorrelated securities, which reduces the variance of the portfolio as a whole. By reducing the variance, it reduces the risk of the portfolio. However, the performance-asset ratio is expected to differ between the different strategies of funds. (GETMANSKY, 2012).

Therefore, to maintain competitive advantage, resource allocators must monitor some characteristics of funds in which they invest (average market value, number of positions and liquidity), checking whether the growth in assets is causing changes in the process and, if necessary, taking action before performance is reduced. (GENTILINI, 2014).

The relationship between age, size and alpha generation was also studied by Gao et al (2012). According to the authors, as fund investors seek better returns, the likelihood of liquidation decreases, as there is an increase in flow to these funds. However, as investors seek returns by category (diversification), the likelihood of liquidation increases, in view of the effects of competition. Therefore, the performanceage-size ratio of the asset assumes different functional forms, for different categories, and depends on the restrictions of each one of them.

The fund whose strategy is to operate with limited capacity and with assets in a more illiquid portfolio is the most likely to exhibit a concave behavior. Concave behavior is when the best performing funds do not grow proportionally to the market average. Thus, these funds may choose not to grow so fast so as not to face diminishing returns. (GETMANSKY, 2012). 
It is the example of the so-called "Event Driven" strategy fund. The hedge fund, which has no limitations and adopts net strategies, is less likely to exhibit such behavior, as is the case the fund that operates jointly. An example is the "Fund of Funds", which is the fund that buys shares from other funds, combining strategies. (GETMANSKY, 2012; AGARWAL et al, 2009).

The reluctance of successful hedge fund managers to accept new money, that is, to open for new contributions, may be indicative of diminishing returns in the industry as a whole. Contrary to similar studies in the mutual funds industry, Goetzmann et al (2001) found that large funds and with superior performance do not issue new shares, in fact they buy back the existing ones. This is consistent with the hypothesis that hedge funds have important limits for growth. Therefore, to the extent that managers engage in "arbitrage in expectations", the strategy's success creates its own limitations.

Managers with greater flexibility can invest in arbitrage opportunities that can take some time to become profitable due to the risk of noise. Noise risk is understood as short-term speculations that hinder the investment. Longer periods of blocking and restriction should be associated with better performance due to greater investment flexibility. This is consistent with the notion that this situation provides the manager with investment in illiquid securities, thus potentially being able to capture premiums obtained through liquidity risk. (AGARWAL et al, 2009).

Boyson (2008) and Joenväärä et al (2012) identify that some of the reasons for the negative relationship between fund size and alpha generation are due to the greater number of capacity restrictions, hierarchy costs and reserve of liquid securities. Thus, according to Avramov et al (2013), increasing restrictions decreases the performance of funds. Joenväära et al (2019) demonstrate that the persistence of fund's performance is significantly reduced when the rebalancing rules reflect size and liquidity restrictions, but it does not eliminate the persistence of performance at shorter rebalancing frequencies.

According to Avramov et al (2013), another relevant factor that must be taken into account when the investor seeks an investment fund is the sensitivity of fund's performance to economic conditions. Vayanos (2004) shares this idea and concludes in his studies that liquidations of funds are rare in normal times, but increase in times of crisis, confirming that economic conditions influence the results of funds.

Analyzing the research, it is clear that the authors are concerned with understanding whether hedge funds have a real capacity to present good and consistent returns over time. In addition, understand the factors that contribute to the generation of alpha. In general, there seems to be a consensus among authors about the fact that investment funds with less equity surpass their large peers. This is because the size of the investment fund is directly linked to the restrictions that the fund assumes. In addition, when a fund's equity increases, managers will have to explore more markets in order to accommodate the allocation of new resources, markets that are often less known to managers. In addition, funds are facing more problems with regard to asset liquidity.

Thus, it is important that investors are aware of the conditions of funds, so that they are able to invest in funds that have greater alpha generation capacity. This article studies the effects (net funding, age, volatility and situation) on the life cycle of Brazilian hedge funds.

\section{Method}

The database was provided by the company Quantum Axis (2019). Data collection was carried out on $11 / 14 / 2019$ and covers from 2010 to 2018 . The database is used for empirical analysis.

Four groups of data were collected: net fund flows (R\$), fund performance (\%), age (years) and status of fund. The status of funds are normal operation, merged and liquidated.

Funds that did not present any information on the performance fund in the period 2010 to 2018 were removed from the database. 
If a fund is liquidated or merged at time $t$ then its performance is zero.

The indicators used are measured on different scales, requiring standardization of data. For standardization, the $z$-value statistic was used. The standardized value $z$ preserves the data distribution. According to the World Economic Forum report:

Z-scores are expressed as standard deviations from the mean. The mean is zero and has a standard deviation of one. This means that all data points above the mean are expressed as positive scores and all data below the mean are expressed as negative scores. The $\mathrm{z}$-scores methodology is based on an assumption of the normal distribution. A standard deviation of plus (minus) 1 represents the area 34.13\% above (below) the mean (zero) and a standard deviation of plus (minus) 2 represents the area $47.72 \%$ above (below) the mean. The $z$-score of a data point indicates the number of standard deviations above or below the mean. So a $z$-score of -2 is exactly two standard deviations, or $47.72 \%$, below the mean. ((2013, p. 8).

Outliers were removed from the database too. Funds that had values greater than +3 or less than -3 were excluded.

In the end, the database contains 8445 hedge funds and 22090 observations.

It is necessary to define some variables, what is done next.

Net fund flow is the difference between the value of the resources invested in a fund and the value of the resources redeemed, net of income tax, from the same fund, in a period (QUANTUM AXIS, 2019). Net fund flows is calculated by equation 1 :

$$
\mathrm{NFF}=\mathrm{RI}-\mathrm{RW}-\mathrm{RWIT}
$$

NFF: net fund flows in the period between the dates T1 and Tn

RI: resources invested in a fund in the period between the dates T1 and Tn

RW: resources withdrawals from a fund in the period between the dates T1 and Tn

RWIT: resources withdrawals from a fund for payment of income tax between the period T1 and Tn

The fund performance is the relative change in the price of an asset in a period (QUANTUM AXIS, 2019). Fund performance is givem by equation 2 :

$$
\mathrm{FP}=(\mathrm{PTn} \div \mathrm{PT} 1)-1
$$

FP: fund performance on an asset in the period between dates T1 e Tn

PTn: price of an asset on the date Tn

PT1: price of an asset on the date T1

The annualized average alpha is given by equation 3:

$$
\text { Alpha }=\text { fund performance }- \text { annualized CDI return }
$$

The annualized CDI return is the annualized Interbank Deposit Certificate (CDI) interest rate (\%), extracted from the BACEN database (2020). The data are available in Table 1. 
Table 1 - Annualized CDI return (\%)

\begin{tabular}{c|c|c|c|c|c|c|c|c|c|c}
\hline Date & $31 / 12 / 10$ & $30 / 12 / 11$ & $31 / 12 / 12$ & $31 / 12 / 13$ & $31 / 12 / 14$ & $31 / 12 / 15$ & $30 / 12 / 16$ & $29 / 12 / 17$ & $31 / 12 / 18$ & $14 / 11 / 19$ \\
\hline $\begin{array}{c}\text { Annualized CDI } \\
\text { return (\%) }\end{array}$ & 10,64 & 10,87 & 6,90 & 9,77 & 11,57 & 14,14 & 13,63 & 6,89 & 6,40 & 4,90 \\
\hline
\end{tabular}

Source: BACEN database (2020)

According to Barras et al (2010), a fund is said qualified when it has a positive alpha. In this case, managers have a real capacity to generate surplus returns for the funds, being able to choose sufficient stocks to overcome their costs and expenses over the period.

Volatility is measured by the alpha amplitude between two years. The greater the amplitude of a fund, the more volatile it is, and vice versa. Funds with only an alpha observed in the period were excluded due to the impossibility of calculating the amplitude.

The models to be tested in this paper are now defined. The paper has two models.

First, the paper analyses how current fund flows is affected by some drivers. For data analysis the techniques of multivariate statistics were used. The simulation of multiple linear regression is performed using the Ordinary Least Square (MQO) estimation method and the stepwise procedure. An equation is established, which is described below:

$$
\mathrm{CNFF}=\alpha+\beta 1 * \mathrm{LNFF}+\beta 2 * \mathrm{CA}+\beta 3 * \mathrm{LA}+\beta 4 * \text { Age }+\beta 5 * \text { Amplitude }+\varepsilon
$$

$\mathrm{CNFF}=$ Current net fund flows

$\mathrm{LNFF}=$ Lagged net fund flows

$\mathrm{CA}=$ Current alpha

LA = Lagged alpha

Age $=$ Age of fund

Amplitude $=$ Alpha amplitude

$\varepsilon=$ Error term

$\alpha=$ Constant

$\beta=$ Angular coefficient of independent variable

The angular coefficient indicates the degree and direction of the relationship between the dependent variable and the independent variable.

Some pre-requisites are needed to perform multiple linear regression.

To verify if there is multicollinearity between the independent variables, the Variance Inflation Factor (VIF) statistic is used. According to Favero et al. (2009), VIF values greater than 5 indicate the presence of multicollinearity.

To verify if there is autocorrelation of the residues, the Durbin-Watson test is used. Durbin-Watson statistic (DW) involves the calculation of a test based on the residuals of the least squares method, to test the null hypothesis of the absence of autocorrelation. DW between $\mathrm{dL}$ and $\mathrm{dU}$ indicates that there is no autocorrelation of the residues. The values of $\mathrm{dL}$ and $\mathrm{dU}$ are obtained taking into account the number of independent variables $(\mathrm{k})$ and the number of observations in the sample (n). 
To verify the regression degree of explanation, the $\mathrm{R}$ square is analysed. $\mathrm{R}$ square values are between zero and one. Values close to one indicate a high degree of explanation of the model. Values close to zero indicate a low degree of explanation of the model. According to Cohen (1988), for the area of Social and Behavioral Sciences, when the $\mathrm{R}$ square is near to $2 \%$, the model is classified as having a minor effect; if $\mathrm{R}$ square is near to $13 \%$, the effect is medium, and when $\mathrm{R}$ square is near to $26 \%$, the effect is major. Tests are performed at a 95\% confidence level using SPSS statistical software, version 24.

The model's hypotheses are:

Hypothesis 1: The fund's current alpha positively affects current net fund flows.

Hypothesis 2: The lagged alpha positively affects current net fund flows.

Hypothesis 3: Lagged net fund flows positively affects current net fund flows.

Hypothesis 4: Age negatively affects current net fund flows.

Hypothesis 5: The alpha amplitude negatively affects current net fund flows.

This model is used to analyze all funds and funds classified by category. For the analysis by category, the Anbima classification was used. Description of categories is available in Appendix A.

In the second model, the paper analyses whether fund flows and fund performance affect the liquidation probability or merged probability.

The funds were divided into two groups. The first group is composed of funds in normal operation. The second group is composed of liquidated or merged funds.

For data analysis the techniques of multivariate statistics were used. A binary logistic regression simulation is performed. An equation is established, which is described below:

$$
\text { Liquidation }=\alpha+\beta 6 * \mathrm{LNFF}+\beta 7 * \mathrm{CA}+\beta 8 * \mathrm{LA}+\beta 9 * \text { Age }+\varepsilon
$$

Liquidation $=$ Fund classification by group, with 0 for normal operation and 1 for liquidated and merged $\mathrm{LNFF}=$ Lagged net fund flows

$\mathrm{CA}=$ Current alpha

LA = Lagged alpha

Age $=$ Age of fund

$\varepsilon=$ Error term

$\alpha=$ Constant

$\beta=$ Angular coefficient of independent variable

Some pre-requisites are needed to perform binary logistic regression.

To use binary logistic regression, each independent variable must have at least ten observations and each category of an independent variable must have at least five cases. These two pre-requisites are met. 
To verify if there is multicollinearity between the independent variables, the Variance Inflation Factor (VIF) statistic is used. VIF above five indicates there is multicollinearity.

The third and last prerequisite is the existence of outliers. This issue is checked again along with the logistic regression.

The model's hypotheses are:

Hypothesis 6: Lagged net fund flows negatively affects the probability of fund liquidation.

Hypothesis 7: Current alpha negatively affects the probability of fund liquidation.

Hypothesis 8: Lagged alpha negatively affects the probability of fund liquidation.

Hypothesis 9: Age positively affects the probability of fund liquidation.

\section{Presentation and analysis of results}

The section begins with the characteristics of the sample. After, the paper analyses how current fund flows is affected by some drivers using multiple linear regression. Next, the paper analyses how categories affects the relation between fund flows and performance. Lastly, the paper analyses whether flow and performance affect the liquidation probability.

\section{General characteristics of the sample}

The database consists of 8445 multimarket funds (Table 2) distributed throughout 2010 to 2018, of which: $58 \%$ of the merged funds are up to four years old; $68 \%$ of liquidated funds are up to four years old; $73 \%$ of funds that are in normal operation are up to six years old; and only $8 \%$ of funds in normal operation are more than 8 years old (Table 2).

Table 2 - Amount of funds according to age and situation

\begin{tabular}{l|cc|cc|cc|cc}
\hline \multicolumn{1}{c|}{ Period } & \multicolumn{2}{|c|}{ Normal operation } & \multicolumn{2}{|c|}{ Merged } & \multicolumn{2}{c}{ Liquidated } & \multicolumn{2}{c}{ Total } \\
\hline $0<\mathrm{T} \leq 2$ years & 1235 & $22 \%$ & 83 & $17 \%$ & 473 & $20 \%$ & 1791 & $21 \%$ \\
\hline $2<\mathrm{T} \leq 4$ years & 1609 & $29 \%$ & 206 & $41 \%$ & 1136 & $48 \%$ & 2951 & $35 \%$ \\
\hline $4<\mathrm{T} \leq 6$ years & 1247 & $22 \%$ & 137 & $27 \%$ & 521 & $22 \%$ & 1905 & $23 \%$ \\
\hline $6<\mathrm{T} \leq 8$ years & 1013 & $18 \%$ & 56 & $11 \%$ & 194 & $8 \%$ & 1263 & $15 \%$ \\
\hline $8<\mathrm{T} \leq 10$ years & 474 & $8 \%$ & 18 & $4 \%$ & 43 & $2 \%$ & 535 & $6 \%$ \\
\hline \multirow{2}{*}{ Total } & 5578 & $100 \%$ & 500 & $100 \%$ & 2367 & $100 \%$ & 8445 & $100 \%$ \\
& $66 \%$ & & $6 \%$ & & $28 \%$ & & $100 \%$ & \\
\hline
\end{tabular}

Source: Research data 
Table 3 - Number of funds created, merged, liquidated and in operation in the year

\begin{tabular}{|c|c|c|c|c|c|c|c|c|}
\hline \multirow{2}{*}{$\begin{array}{l}\text { Year } \\
2010\end{array}$} & \multicolumn{2}{|c|}{$\begin{array}{l}\text { Number of funds } \\
\text { created in the year }\end{array}$} & \multicolumn{2}{|c|}{$\begin{array}{l}\text { Number of funds } \\
\text { merged in the year }\end{array}$} & \multicolumn{2}{|c|}{$\begin{array}{l}\text { Number of funds } \\
\text { liquidated in the year }\end{array}$} & \multicolumn{2}{|c|}{$\begin{array}{l}\text { Number of funds in } \\
\text { operation in the year }\end{array}$} \\
\hline & 1056 & $13 \%$ & 0 & $0 \%$ & 0 & $0 \%$ & 1056 & $13 \%$ \\
\hline 2011 & 995 & $12 \%$ & 0 & $0 \%$ & 0 & $0 \%$ & 2050 & $24 \%$ \\
\hline 2012 & 1103 & $13 \%$ & 25 & $5 \%$ & 97 & $4 \%$ & 3142 & $37 \%$ \\
\hline 2013 & 1208 & $14 \%$ & 33 & $7 \%$ & 182 & $8 \%$ & 4228 & $50 \%$ \\
\hline 2014 & 831 & $10 \%$ & 54 & $11 \%$ & 308 & $13 \%$ & 4850 & $57 \%$ \\
\hline 2015 & 842 & $10 \%$ & 80 & $16 \%$ & 410 & $17 \%$ & 5330 & $63 \%$ \\
\hline 2016 & 1085 & $13 \%$ & 93 & $19 \%$ & 451 & $19 \%$ & 5925 & $70 \%$ \\
\hline 2017 & 1325 & $16 \%$ & 82 & $16 \%$ & 322 & $14 \%$ & 6703 & $79 \%$ \\
\hline 2018 & & $0 \%$ & 59 & $12 \%$ & 310 & $13 \%$ & 6298 & $75 \%$ \\
\hline 2019 & & $0 \%$ & 74 & $15 \%$ & 287 & $12 \%$ & & $0 \%$ \\
\hline Total & 8445 & $100 \%$ & 500 & $100 \%$ & 2367 & $100 \%$ & 8445 & $100 \%$ \\
\hline
\end{tabular}

Source: Research data

Table 3 presents the annual number of entries into and exits out of the database from 2010 to 2018. Analyzing the data, 8445 funds are created, 500 funds are merged $(6 \%)$ and 2367 are liquidated (28\%). From 2015 to 2017, there is the highest percentage of mergers (51\%) and liquidations $(50 \%)$ of hedge funds.

According to Avramov et al (2013), funds are sensitive to economic conditions, which may be one of the factors explaining the increase in the percentage of funds merged and liquidated in this period.

Barbosa Filho (2017) informs that the Brazilian economy has been in recession since the beginning of the second quarter of 2014, according to information provided by the Economic Cycle Dating Committee (Codace) of the Getúlio Vargas Foundation. From 2014 to 2016, the Brazilian per capita product fell by about $9 \%$. The government's loss of financial capacity has reduced investments in the economy since 2015, increasing country risk, long-term interest rates and uncertainty. This caused consumption and investment to drop substantially from 2015 to 2016. Monetary policy and the recomposition of prices to return inflation to its target contributed to the recession.

Table 4 presents the number of funds by category and status. Most of funds in normal operation (83\%) are concentrated in the free $(36 \%)$ and foreign investment $(47 \%)$ categories. The same situation occurs in the case of merged (free $=26 \%$ and foreign investment $=17 \%$ ) and liquidated funds (free $=31 \%$ and foreign investment $=19 \%$ ).

The "Others" group is the group where the funds that cannot be classified in any of the eleven categories listed by Anbima (2020) are located. In this group, two categories of funds stand out: multi-strategy and multi-managers. These two categories account for $21 \%$ of merged funds and $26 \%$ of liquidated funds. No multi-strategy fund or multi-managers fund is in normal operation on 11/14/2019. 
Table 4 - Number of funds by category and situation

\begin{tabular}{|c|c|c|c|c|c|c|c|c|}
\hline \multirow{2}{*}{$\begin{array}{l}\text { Category } \\
\text { Balanced }\end{array}$} & \multicolumn{2}{|c|}{ Normal operation } & \multicolumn{2}{|c|}{ Merged } & \multicolumn{2}{|c|}{ Liquidated } & \multicolumn{2}{|c|}{ Total } \\
\hline & 85 & $2 \%$ & 7 & $1 \%$ & 33 & $1 \%$ & 125 & $1 \%$ \\
\hline Dynamic & 175 & $3 \%$ & 26 & $5 \%$ & 91 & $4 \%$ & 292 & $3 \%$ \\
\hline Macro & 327 & $6 \%$ & 53 & $11 \%$ & 144 & $6 \%$ & 524 & $6 \%$ \\
\hline Trading & 11 & $0 \%$ & 4 & $1 \%$ & 4 & $0 \%$ & 19 & $0 \%$ \\
\hline Long and short - neutral & 21 & $0 \%$ & 12 & $2 \%$ & 15 & $1 \%$ & 48 & $1 \%$ \\
\hline Long and short - directional & 48 & $1 \%$ & 22 & $4 \%$ & 55 & $2 \%$ & 125 & $1 \%$ \\
\hline \begin{tabular}{l|l} 
Interest and currencies \\
\end{tabular} & 105 & $2 \%$ & 10 & $2 \%$ & 54 & $2 \%$ & 169 & $2 \%$ \\
\hline Free & 1982 & $36 \%$ & 130 & $26 \%$ & 738 & $31 \%$ & 2850 & $34 \%$ \\
\hline Protected capital & 18 & $0 \%$ & 14 & $3 \%$ & 56 & $2 \%$ & 88 & $1 \%$ \\
\hline Specific strategy & 157 & $3 \%$ & 20 & $4 \%$ & 67 & $3 \%$ & 244 & $3 \%$ \\
\hline Foreign investment & 2646 & $47 \%$ & 87 & $17 \%$ & 455 & $19 \%$ & 3188 & $38 \%$ \\
\hline Others & 3 & $0 \%$ & 115 & $23 \%$ & 655 & $28 \%$ & 773 & $9 \%$ \\
\hline Multi-strategy & 0 & $0 \%$ & 84 & $17 \%$ & 474 & $20 \%$ & 558 & $7 \%$ \\
\hline Multi-manager & 0 & $0 \%$ & 19 & $4 \%$ & 144 & $6 \%$ & 163 & $2 \%$ \\
\hline Others & 3 & $0 \%$ & 12 & $2 \%$ & 37 & $2 \%$ & 52 & $1 \%$ \\
\hline Total & $\begin{array}{l}5578 \\
66 \% \\
\end{array}$ & $100 \%$ & $\begin{array}{l}500 \\
6 \% \\
\end{array}$ & $100 \%$ & $\begin{array}{l}2367 \\
28 \% \\
\end{array}$ & $100 \%$ & $\begin{array}{l}8445 \\
100 \% \\
\end{array}$ & $100 \%$ \\
\hline
\end{tabular}

Source: Research data

In the next sections, the situation of funds will be considered the classification received according to the identification made on $14 / 11 / 2019$. Therefore, if the fund was merged or liquidated in a given year, within the period from 2010 to 2018, it receives this classification from the moment of its creation for the purpose of analysis.

\section{Multiple linear regression}

The model simulations are performed using multiple linear regression. Table 5 presents the results of the simulations. The choice of the best model took into account the $\mathrm{R}$ square, the absence of multicollinearity, absence of autocorrelation of the residues, and the largest number of independent variables that should remain in the regression model. 
Table 5 - Multiple linear regression

\begin{tabular}{l|c|c|c}
\hline \multicolumn{1}{c|}{ Indicators } & First simulation & Second simulation & Final simulation \\
\hline P-value ANOVA & 0.000 & 0.000 & 0.000 \\
\hline R square & 0.039 & 0.039 & 0.039 \\
\hline Durbin-Watson & 1.780 & 1.780 & 1.780 \\
\hline Variance Inflation Factor & & & 1.007 \\
\hline Lagged net fund flows & 1.013 & 1.013 & \\
\hline Current alpha & 418.548 & & 1.719 \\
\hline Lagged alpha & 381.450 & 1.740 & \\
\hline Age & 1.013 & 1.012 & \\
\hline Alpha amplitude & 710.175 & 1.728 & \\
\hline P-value of coefficients & & & 0.000 \\
\hline Constant & 0.873 & 0.927 & \\
\hline Lagged net fund flows & 0.000 & 0.000 & 0.000 \\
\hline Current alpha & 0.076 & & 0.000 \\
\hline Lagged alpha & 0.313 & 0.000 & \\
\hline Age & 0.525 & 0.561 & \\
\hline Alpha amplitude & 0.249 & 0.000 & \\
\hline Standardized coefficients & & & \\
\hline Lagged net fund flows & 0.170 & 0.170 & \\
\hline Current alpha & 0.252 & & \\
\hline Lagged alpha & -0.137 & 0.104 & \\
\hline Age & -0.004 & -0.004 & \\
\hline Alpha amplitude & -0.213 & 0.115 & \\
\hline
\end{tabular}

Source: Research data

The regression presents statistical significance ( $\mathrm{p}$-value $=0.000)$ according to the ANOVA test at a 95\% confidence level.

However, the first simulation indicates multicollinearity between the current alpha (VIF $=418.548)$, lagged alpha $(\mathrm{VIF}=381.450)$ and alpha amplitude $(\mathrm{VIF}=710.175)$ variables. To solve the multicollinearity problem, the current alpha variable is removed.

In the second simulation, the variables that remained in the model do not showed multicollinearity (VIF lagged net fund flows $=1.013$; lagged alpha $=1.740 ;$ age $=1.012 ;$ alpha amplitude $=1.728)$. The constant $(\mathrm{p}$-value $=0.927)$ and age $(\mathrm{p}$-value $=0.561)$ were not statistically significant. Therefore, they were removed from the regression model.

In the final simulation, three independent variables remained in the model because the p-value is less than 0.05 (lagged net fund flows $=0.000$; lagged alpha $=0.000$; alpha amplitude $=0.000$ ).

To verify if there is autocorrelation of the residues in final simulation, the Durbin-Watson test is used. The number of independent variables $(\mathrm{k})$ is 3 and the number of observations is greater than 200, therefore, $\mathrm{dL}=1.74$ and $\mathrm{dU}=1.80$. The value of $\mathrm{DW}(1.780)$ is between $\mathrm{dL}$ and $\mathrm{dU}$. Therefore, there is no residual correlation. 
The final simulation indicates that the model's degree of explanation is 0.039 . This means that $3.9 \%$ of the variations that occur in current net fund flows are explained by variations that occur in the lagged net fund flows, lagged alpha and alpha amplitude. The other $96.1 \%$ are explained by other variables that are not in the proposed regression model. According to Cohen (1988), the model is classified as having a small effect as $3.9 \%$ is close to $2.0 \%$.

Using the information in Table 5 , the following regression equation can be constructed:

$$
\mathrm{CNFF}=0.170 * \mathrm{LNFF}+0.104 * \mathrm{LA}+0.116 * \text { Amplitude }+\varepsilon
$$

The angular coefficient of lagged net fund flows is positive $(+0.170)$, confirming hypothesis 3 that lagged net fund flows positively affects current net fund flows.

The angular coefficient of lagged alpha is positive (+0.104), confirming hypothesis 1 that the current alpha positively affects current net fund flows.

The angular coefficient of alpha amplitude is positive (+0.116), not confirming hypothesis 5 . According to Getmansky (2012) people are less likely to keep their money in a high volatility fund after adjusting the return to the expected volatility. However, this situation does not occur in this sample, indicating that the greater the volatility, the greater the fund flows.

Hypothesis 2 is confirmed, current alpha positively affects current net fund flows, however, the variable was removed to eliminate multicollinearity. Hypothesis 4 is not confirmed because age does not have statistical significance at a 95\% confidence level.

At the end, three out of five results are consistent with the hedge fund literature and as predicted in the hypotheses.

Analyzing the value of the coefficients, the variable lagged net fund flows has the greatest impact (0.170) on the current net fund flows, followed by alpha amplitude (0.116) and lagged alpha (0.104).

\section{Multiple linear regression by categories}

To verify whether the category influences the relationship between the flow and performance, the same first model was estimated for each category. The results are shown in Table 6.

The ANOVA test indicates that the model is significant in all categories ( $\mathrm{p}$-value less than 5\%), except interest and currencies category.

The Durbin-Watson value is between $\mathrm{dL}$ and $\mathrm{dU}$, indicating non-rejection of the null hypothesis and concluding that there is no autocorrelation of residuals in all remained categories.

After adjustments, the remaining independent variables do not show multicollinearity, since the VIF value is not greater than 5 . The variable removed to avoid multicollinearity is current alpha. 
Table 6 - Multiple linear regression by categories

\begin{tabular}{|c|c|c|c|c|c|c|c|c|c|c|c|c|}
\hline Indicators & Balanced & Dynamic & Macro & Trading & $\begin{array}{c}\text { Long and } \\
\text { short - } \\
\text { neutral }\end{array}$ & $\begin{array}{c}\text { Long and } \\
\text { short - } \\
\text { directional }\end{array}$ & $\begin{array}{c}\text { Interest } \\
\text { and } \\
\text { currencies }\end{array}$ & Free & $\begin{array}{c}\text { Protected } \\
\text { capital }\end{array}$ & $\begin{array}{l}\text { Specific } \\
\text { strategy }\end{array}$ & $\begin{array}{c}\text { Foreign } \\
\text { Investment }\end{array}$ & Others \\
\hline P-value ANOVA & 0.000 & 0.000 & 0.000 & 0.018 & 0.005 & 0.000 & \begin{tabular}{|c|}
$\begin{array}{c}\text { Non- } \\
\text { significant } \\
\text { model }\end{array}$ \\
\end{tabular} & 0.000 & 0.005 & 0.001 & 0.000 & 0.000 \\
\hline R square & 0.044 & 0.054 & 0.128 & 0.111 & 0.089 & 0.168 & & 0.041 & 0.068 & 0.031 & 0.089 & 0.104 \\
\hline Durbin-Watson & 1.785 & 1.772 & 1.793 & 1.589 & 1.713 & 1.786 & & 1.775 & 1.748 & 1.789 & 1.793 & 1.787 \\
\hline $\mathrm{n}$ & 474 & 870 & 1.057 & 52 & 117 & 271 & & 7.872 & 159 & 514 & 8.850 & 1.362 \\
\hline $\mathrm{k}$ & 2 & 3 & 3 & 1 & 2 & 2 & & 4 & 2 & 2 & 3 & 3 \\
\hline $\mathrm{d}_{\mathrm{L}}$ & 1.750 & 1.740 & 1.740 & 1.500 & 1.630 & 1.750 & & 1.730 & 1.710 & 1.750 & 1.740 & 1.740 \\
\hline $\mathrm{d}_{\mathrm{U}}$ & 1.790 & 1.800 & 1.800 & 1.590 & 1.720 & 1.790 & & 1.810 & 1.760 & 1.790 & 1.800 & 1.800 \\
\hline \multicolumn{13}{|l|}{ Variance Inflation Factor } \\
\hline Lagged net fund flows & 1.014 & 1.012 & 1.050 & 1.000 & & & & 1.003 & & & 1.021 & 1.024 \\
\hline \multicolumn{13}{|l|}{ Current alpha } \\
\hline Lagged alpha & 1.014 & 1.529 & 1.848 & & 1.226 & 1.319 & & 1.705 & 2.066 & 1.708 & 2.137 & 1.309 \\
\hline Age & & & & & & & & 1.003 & & & & \\
\hline Alpha amplitude & & 1.519 & 1.782 & & 1.226 & 1.319 & & 1.700 & 2.066 & 1.708 & 2.106 & 1.294 \\
\hline \multicolumn{13}{|l|}{ P-value of coefficients } \\
\hline Constant & & & & & & & & & 0.005 & & & \\
\hline Lagged net fund flows & 0.000 & 0.000 & 0.000 & 0.018 & & & & 0.000 & & & 0.000 & 0.001 \\
\hline \multicolumn{13}{|l|}{ Current alpha } \\
\hline Lagged alpha & 0.030 & 0.016 & 0.000 & & 0.011 & 0.000 & & 0.000 & 0.044 & 0.009 & 0.000 & 0.000 \\
\hline Age & & & & & & & & 0.043 & & & & \\
\hline Alpha amplitude & & 0.006 & 0.000 & & 0.003 & 0.000 & & 0.000 & 0.001 & 0.000 & 0.000 & 0.000 \\
\hline \multicolumn{13}{|l|}{ Standardized coefficients } \\
\hline Lagged net fund flows & 0.171 & 0.198 & 0.273 & 0.334 & & & & 0.172 & & & 0.274 & 0.106 \\
\hline \multicolumn{13}{|l|}{ Current alpha } \\
\hline Lagged alpha & 0.102 & 0.118 & 0.233 & & 0.258 & 0.407 & & 0.122 & 0.231 & 0.166 & 0.089 & 0.209 \\
\hline Age & & & & & & & & -0.028 & & & & \\
\hline Alpha amplitude & & 0.135 & 0.237 & & 0.298 & 0.406 & & 0.107 & 0.371 & 0.231 & 0.161 & 0.324 \\
\hline
\end{tabular}

Source: Research data

The remaining independent variables are statistically significant at a 95\% confidence level, as they have a p-value less than 0.05 .

$\mathrm{R}$ squared is between 3,1\% (specific strategy category) and 16.8\% (long and short directional category).

Lagged alpha is significant in $10(90,9 \%)$ of the 11 categories. Lagged net fund flows is significant in 7 $(63,6 \%)$ of the 11 categories. Alpha amplitude variable is significant in $9(81,8 \%)$ of the 11 categories.

Age is significant only in the free category, confirming hypothesis 4, age negatively affects current net fund flows, however, the impact on current net fund flows is the smallest among the independent variables (coefficient $=-0.028$ ).

As can be seen, the current net fund flows is predominantly influenced by three variables: lagged net fund flows, lagged alpha and alpha amplitude. However, it is observed that only hypotheses 2 and 3 are confirmed, lagged net fund flows and lagged alpha positively affect current net fund flows. Contrary to theory, alpha amplitude positively affects current net fund flows.

Regarding the intensity of the impact of independent variables on the current net fund flows, lagged net fund flows has the greatest impact most of time, except in the category others where the greatest impact occurs with alpha amplitude. The second variable with the greatest impact is alpha amplitude, followed by lagged alpha. 


\section{Binary logistic regression}

A binary logistic regression was performed to verify whether flow, performance and age are predictors of liquidation or merger of fund. The results are available in Table 7.

The model was significant with $\chi^{2}(4)=1816.037$, $\mathrm{p}$-value $=0.000$ and $\mathrm{RNagelkerke}=0.125$.

Lagged net fund flows, lagged alpha, current alpha and age are significant predictors since the p-value (0.000) is less than 0.05 in all independent variable and the constant.

The sign of all coefficients is negative. This means that each additional unit of the independent variable, the chance of liquidation or incorporation of fund decreases. The highest coefficient belongs to age (0.522), followed by current alpha $(-0.451)$, lagged net fund flows $(-0.192)$ and lagged alpha $(-0.107)$.

These results confirm hypotheses 6, 7 and 8. Thus, it can be concluded that current and lagged alphas, and lagged net fund flows negatively influence the probability of liquidation or merger of fund. On the other hand, hypothesis 9 is not confirmed, that is, age does not affects positively the probability of liquidation or merger of fund.

Table 7 - Binary logistic regression

\begin{tabular}{|c|c|c|c|c|c|c|}
\hline \multirow{2}{*}{ Parameter } & \multirow{2}{*}{ Coefficient } & \multirow{2}{*}{$\begin{array}{l}\text { Wald Chi- } \\
\text { Square }\end{array}$} & \multirow{2}{*}{ P-value } & \multirow{2}{*}{ Odds Ratio } & \multicolumn{2}{|c|}{$95 \%$ C.I. para Odds Ratio } \\
\hline & & & & & Lower & Upper \\
\hline Constant & -1.153 & 4316.747 & 0.000 & 0.316 & & \\
\hline Lagged net fund flows & -0.192 & 103.282 & 0.000 & 0.826 & 0.796 & 0.857 \\
\hline Current alpha & -0.451 & 660.213 & 0.000 & 0.637 & 0.615 & 0.659 \\
\hline Lagged alpha & -0.107 & 40.136 & 0.000 & 0.899 & 0.869 & 0.929 \\
\hline Age & -0.522 & 720.362 & 0.000 & 0.593 & 0.571 & 0.616 \\
\hline
\end{tabular}

Source: Research data

At the end, three out of four results are consistent with the hedge fund literature and as predicted in the hypotheses.

\section{Final considerations}

This paper studies the lifecycle drivers of hedge funds in Brazil from 2010 to 2018. To understand the lifecycle of hedge funds it is important to understand the interrelationships of fund characteristics, namely, flow, performance, age and volatility. The analysis was divided into three parts.

First, we analyzed how lagged net fund flows, lagged alpha, current alpha, age and alpha amplitude affect current net fund flows using a linear relationship. As expected, lagged net fund flows and lagged alpha positively affect current net fund flows, however, contrary to expectations, alpha amplitude positively influences current net fund flows, and no evidence was found that age influence current net fund flows. Current alpha positively affects current net fund flows however the variable is removed to eliminate the multicollinearity problem. Lagged net fund flow has the greatest impact on the current net fund flows, followed by alpha amplitude and lagged alpha.

Second, the linear relationship between performance and flow by hedge fund category was analyzed. The funds were classified according to Anbima's definition. The results were similar to those obtained for the total sample in most categories, with the exception of the interest and currency category, where the regression model did not show statistical significance. 
At the end, three out of five results are consistent with the hedge fund literature and as predicted in the hypotheses.

Third, the influence of performance and flow on the fund's probability of survival was analyzed using logistic regression. The results indicate that lagged net fund flows, current alpha, lagged alpha and age have a negative influence on the probability of liquidation or merger of fund. Hypotheses 6,7 and 8 are confirmed.

The results contribute to a better understanding of the effects of the hedge fund's survival probabilities, in addition to contributing to a better understanding of investment opportunities.

This paper provides an analysis of the performance of Brazilian hedge funds using only a few variables discussed in the literature. Future work may include investigating the influence of portfolio diversification on alpha generation and the influence of blocking and restricting on investment flexibility.

\section{References}

Anbima (2020a). Ranking de Gestores de Fundos de Investimento. São Paulo: ANBIMA.

Anbima (2020b). Cartilha da nova classificação de fundos. São Paulo: ANBIMA.

Agarwal, V., Daniel, N., \& Naik, N. Y. (2009). Role of managerial incentives and discretion in hedge fund performance: working paper. Journal of Finance, 64, 2221-2256.

Anderson, D. R., Sweeney, D. J., \& Williams, T. A. (2007). Estatística aplicada à administração e economia. São Paulo: Thomson Learning.

Aragon, G., Liang, B., \& Park, H. (2014). Onshore and offshore hedge funds: are they twins? Management Science, 60(1), 74-91.

Assaf Neto, A. (2006). Mercado Financeiro, $7^{\circ}$ ed., São Paulo: Editora Atlas.

Avramov, D., Kosowski, R., Naik, N. Y., \& Teo, M. (2011). Hedge funds, managerial skill, and macroeconomic variables. Journal of Financial Economics, Amsterdã, 99(3), 672-692.

Avramov, D., Barras, L., \& Kosowski, R. (2013). Hedge Fund Return Predictability Under the Magnifying Glass. Journal of Financial and Quantitative Analysis, Cambridge, 48(4), 1057-1083.

Bacen (2021). Sistema Gerenciador de Séries Temporais: CDI anualizada base 252.

Barbosa Filho, F. H. (2017). A crise econômica de 2014/2017. Estudos Avançados, 31(89), 51-60.

Barras, L., Scaillet, O., \& Wermers, R. (2010). False Discoveries in Mutual Fund Performance: Measuring Luck in Estimated Alphas. The Journal of Finance, 65(1), 179-216.

Berk, J. B., \& Green, R. C. (2004). Mutual Fund Flows and Performance in Rational Markets. Journal of Political Economy, 112(6), 1269-1295.

Boyson, N. M. (2008). Hedge Fund Performance Persistence: A New Approach. Financial Analysts Journal, 64(6), 27-44.

Bragança, M. M. O., \& Pessoa, M. S. (2017). Análise de Performance de Fundos de Investimento Multimercado no Brasil. Revista Brasileira de Finanças, Rio de Janeiro, 15(1), 93-134.

Cavalcante, F., Misume, J., \& Rudge, L. F. (2005). Mercado de Capitais - O que é e como funciona, $6^{\circ}$ ed., Rio de Janeiro: Editora Campus.

Cohen, J. (1988). Statistical Power Analysis for the Behavioral Sciences. 2. ed. New York: Lawrence Erlbaum.

Costa, F. N. (1999). Economia monetária e financeira. São Paulo, Makron Books.

Dancey, C. P., \& Reidy, J. (2019). Estatística sem matemática para psicologia: usando SPSS para Windows. 7. ed. Porto Alegre: Penso Artmed, 2019. 
Eboli, R. L. (2006). Hedge Funds: Uma análise do desempenho da indústria no Brasil. 2006. 36 f. Monografia (Especialização) - Curso de Economia, Departamento de Economia, Pontifícia Universidade Católica do Rio de Janeiro, Rio de Janeiro.

Fávero, L. P., Belfiore, P., Silva, F. L., \& Chan, B. L. (2009). Análise de dados: modelagem multivariada para tomada de decisões. Rio de Janeiro: Elsevier.

Fung, W., Hsieh, D. A., Naik, N. Y., \& Ramadorai, T. (2008). Hedge Funds: Performance, Risk, and Capital Formation. The Journal of Finance, 63(4), 1777-1803.

Gao, C., Haight, T., Yin, C., \& Zhang, C. (2019). The Performance Life Cycle of Hedge Funds: Can Investors Achieve Lasting Performance? Social Science Research Network (SSRN), New York, 1-86.

Gentilini, A. (2014). How AUM growth inhibits performance. Novus Research, New York, 1-19.

Getmansky, M. (2012). The life cycle of hedge funds: fund flows, size, competition, and performance. Social Science Research Network (SSRN), New York, 1-71.

Goetzmann, W. N., Ingersoll Junior, J., \& Ross, S. A. (2001). High-Water Marks and Hedge Fund Management Contracts. 2001. 39 f. Tese (Doutorado) - Curso de Finance, International Center For Finance, Yale School Of Management, New Haven.

Goulart, A. M. C. (2003). Evidenciação contábil do risco de mercado por instituições financeiras no Brasil. 2003. 201

f. Dissertação (Mestrado) - Curso de Controladoria e Contabilidade, Faculdade de Economia, Administração e Contabilidade, Universidade de São Paulo, São Paulo.

Joenväärä, J., Kosowski, R., \& Tolonen, P. (2019). The Effect of Investment Constraints on Hedge Fund Investor Returns. Journal of Financial and Quantitative Analysis, Cambridge, 1539-1571.

Joenväärä, J., Kosowski, R., \& Tolonen, P. (2012). New 'Stylized facts' about Hedge Funds and Database Selection. EDHEC Business School, 1-84.

Machado, K. G. (2008). Análise de desempenho dos fundos de renda fixa e referenciado no período de 2005 a 2007. 2008. 108 f. Dissertação (Mestrado) - Curso de Ciências em Engenharia de Produção, Programa de Pósgraduação em Engenharia de Produção, Universidade Federal de Itajubá, Itajubá.

Petersen, A. (2007). A Indústria de Hedge Fund no Brasil: uma avaliação preliminar. 2007. 45 f. Dissertação (Mestrado) - Curso de Finanças e Economia Empresarial, Escola de Pós-Graduação em Economia da Fundação Getúlio Vargas, Fundação Getúlio Vargas, São Paulo.

Quantum Axis (2019). Base de dados.

Ramadorai, T. (2013). Capacity constraints, investor information, and hedge fund returns. Journal of Financial Economics, 107(2), 401-416.

Vayanos, D. (2004). Flight to quality, flight to liquidity, and the pricing of risk. NBER Working Paper, n. 10327, 1-55.

World Economic Forum. (2013). The Human Capital Report. Suiça: World Economic Forum. 


\section{Appendix: Anbima classification}

The company Quantum Axis uses the Anbima classification. The following is a list of category descriptions taken directly from the Anbima (2020) booklet.

Figure 1 - Funds by allocation

\begin{tabular}{|c|c|}
\hline Category & Description \\
\hline Balanced & $\begin{array}{l}\text { They seek long-term returns by purchasing a variety of asset classes, including fund shares. These } \\
\text { funds have a pre-determined allocation strategy and must specify the mix of investments in the } \\
\text { various asset classes, including tactical shifts and/or explicit rebalancing policies. The fund's } \\
\text { performance indicator must follow the specified investment mix (asset allocation benchmark), } \\
\text { and therefore cannot be compared to a single asset class (eg, 100\% CDI). Funds in this } \\
\text { subcategory cannot have financial exposure greater than 100\% of PL. Do not admit leverage. }\end{array}$ \\
\hline Dynamic & $\begin{array}{l}\text { They seek long-term returns by investing in various asset classes, including fund shares. These } \\
\text { funds have an asset allocation strategy without, however, being committed to a predetermined } \\
\text { mix of assets. The allocation policy is flexible, reacting to market conditions and the investment } \\
\text { horizon. The acquisition of shares of funds that have financial exposure greater than } 100 \% \text { of } \\
\text { their respective Shareholders' Equity is permitted. They admit leverage. }\end{array}$ \\
\hline Macro & $\begin{array}{l}\text { Funds that carry out operations in various asset classes (fixed income, variable income, foreign } \\
\text { exchange, etc.), with investment strategies based on medium and long-term macroeconomic } \\
\text { scenarios. }\end{array}$ \\
\hline Trading & $\begin{array}{l}\text { Funds that carry out operations in various asset classes (fixed income, variable income, foreign } \\
\text { exchange, etc.), exploring opportunities for } 25 \text { gains from short-term movements in asset prices. }\end{array}$ \\
\hline $\begin{array}{l}\text { Long and Short - } \\
\text { Directional }\end{array}$ & $\begin{array}{l}\text { Funds that carry out asset and derivative operations linked to the variable income market, building } \\
\text { long and short positions. The result must come, mainly, from the difference between these } \\
\text { positions. The remaining cash resources must be invested in Fixed Income - Low Duration - } \\
\text { Investment Grade fund quotas or in assets allowed to them, provided the rules that determine } \\
\text { the composition of the ANBIMA-type portfolio are preserved. }\end{array}$ \\
\hline $\begin{array}{l}\text { Long and Short - } \\
\text { Neutral }\end{array}$ & $\begin{array}{l}\text { Funds that carry out asset and derivative operations linked to the variable income market, building } \\
\text { long and short positions, with the objective of maintaining a net financial exposure limited to } 5 \% \text {. } \\
\text { The remaining cash resources must be invested in Fixed Income - Low Duration - Investment } \\
\text { Grade fund quotas or in assets allowed to them, provided that the rules that determine the } \\
\text { composition of the ANBIMA Type portfolio are preserved. }\end{array}$ \\
\hline $\begin{array}{l}\text { Interest and } \\
\text { Currencies }\end{array}$ & $\begin{array}{l}\text { Funds that seek long-term returns via investments in fixed-income assets, admitting strategies } \\
\text { that imply interest rate risk, price index risk and foreign currency risk. Strategies that imply } \\
\text { exposure to variable income (stocks, etc.) are excluded. }\end{array}$ \\
\hline Free & Funds without commitment to concentration on any specific strategy. \\
\hline Protected Capital & $\begin{array}{l}\text { Funds that seek returns in risk markets seeking to protect, partially or totally, the principal } \\
\text { invested. }\end{array}$ \\
\hline Specific Strategy & $\begin{array}{l}\text { Funds that adopt an investment strategy that implies specific risks, such as commodities, index } \\
\text { futures. }\end{array}$ \\
\hline $\begin{array}{l}\text { Foreign } \\
\text { Investment }\end{array}$ & Foreign investment. \\
\hline Others & cannot be classified in one of the eleven listed categories. \\
\hline
\end{tabular}

Source: Adapted from Anbima (2020b) 